\title{
Dynamics of whole community bacterial production and grazing losses in seawater incubations as related to the changes in the proportions of bacteria with different DNA content
}

\author{
Dolors Vaqué*, Emilio O. Casamayor, Josep M. Gasol \\ Departament de Biologia Marina i Oceanografia, Institut de Ciències del Mar-CMIMA (CSIC), Passeig Marítim 37-49, \\ 08003-Barcelona, Spain
}

\begin{abstract}
Natural bacterial assemblages are not physiologically and phenotypically homogeneous. Development of new methodologies, such as flow cytometry, has allowed bacterial types with different degrees of activity (which have been called HighDNA and LowDNA bacteria) to be distinguished on the basis of their DNA content. Because previous data have suggested that HighDNA bacteria are really the active fraction of the community, we hypothesize that the dynamics of bacterial production (BP) and grazing losses should be linked to the changes of this fraction rather than to changes in the whole community. To test our hypothesis we took samples during a cruise in the NW Mediterranean Sea in March 1999 from 6 selected stations placed along 2 transects, 1 perpendicular to the city of Barcelona and the other to Palamós. In each transect we visited 'coastal' (on the continental platform), 'slope' and 'open sea' (>2000 m) stations. Samples were collected at surface and at the deep chlorophyll maximum. Bacterial abundance (total, HighDNA and LowDNA) and BP were determined in in situ samples. Also, 12 experiments were performed to survey the dynamics of HighDNA bacteria (percentage and biomass), $\mathrm{BP}$ and grazing rates inside experimental bottles every 8 to $12 \mathrm{~h}$ for a total period of $44 \mathrm{~h}$. Bacterial abundance was counted and cell volume was estimated by flow citometry, BP was determined by ${ }^{3} \mathrm{H}$-leucine incorporation, and grazing rate was obtained by following the evolution inside the experimental bottles of added 5-([4,6 dichlorotriazin-2yl) amino]-fluorescein-stained Pseudomonas diminuta as fluorescentlabeled bacteria. In situ, BP was higher in coastal and slope stations than in open sea stations. The percentage of HighDNA bacteria ranged between 25 and $87 \%$ and BP between 0.09 and $5.9 \mu \mathrm{Cl}^{-1} \mathrm{~d}^{-1}$, lower in the open sea and higher in the slope station of Palamós. Grazing loss rates followed a similar pattern, from $0.2 \times 10^{5}$ to $2.2 \times 10^{5}$ cells ingested $\mathrm{ml}^{-1} \mathrm{~d}^{-1}$, again lower in the open sea and higher at the coastal station of Palamós. In most of the experiments, BP increased with time following the increase of HighDNA bacteria, while LowDNA bacteria remained practically constant during the whole period. Exponential bacterial growth appeared at 20 to $32 \mathrm{~h}$. Grazing rates were maximal right after the exponential bacterial growth (at 32 to $44 \mathrm{~h}$ ), suggesting that the increase of the HighDNA bacterial fraction in the previous period stimulated grazers to consume it. In both in situ and experimental samples, abundance and biomass of HighDNA bacteria were strongly correlated with BP and grazing rates, but no correlation was found between these variables and LowDNA bacterial abundance. Samples with the lowest percentage of HighDNA bacteria also had low BP and grazing rates. Indeed, the dynamics of BP and grazing losses were better related to changes in HighDNA bacteria, providing further evidence that they can be considered as the 'active' fraction of the whole bacterial community.
\end{abstract}

KEY WORDS: Bacterial biomass - Bacterial production - HighDNA bacteria - LowDNA bacteria · Bacterivory Resale or republication not permitted without written consent of the publisher

\section{INTRODUCTION}

One of the aims of microbial ecologists is to understand the functioning of microbial food webs. We want,

*E-mail: dolors@icm.csic.es for instance, to be able to quantify how much bacterial carbon flows through bacterial grazers (e.g., protists) and to identify the main factors that regulate bacterial ingestion rates. These fundamental questions are not easy to answer. While laboratory studies have shown that a single heterotrophic nanoflagellate (HNF) can

() Inter-Research 2001 
ingest per unit of time a fairly large quantity of bacteria (e.g., the range of bacteria ingested $\mathrm{HNF}^{-1} \mathrm{~h}^{-1}$ is 10 to 254; Fenchel 1982, Sherr et al. 1983), HNF bacterial ingestion rates in natural communities tend to be much lower (e.g., range $<1$ to 20 bacteria $\mathrm{HNF}^{-1} \mathrm{~h}^{-1}$; Landry et al. 1984, Kuuppo-Leinikki \& Kuosa 1990, Vaqué et al. 1992, Leaky et al. 1996). The different grazing impact of protists on heterotrophic bacteria in nature, and hence the carbon that really flows through the bacteria-protist link of the microbial food web, responds to factors that commonly do not vary in laboratory studies where maximal rates of grazing are commonly estimated. For example, temperature, prey, and predator size spectra and abundance are factors that can be maintained constant in the laboratory while in nature they cannot (e.g., Peters 1994, Vaqué et al. 1994 and references therein). Also, several studies have shown that grazers are able, and probably prefer, to ingest preys larger than heterotrophic bacteria (such as cyanobacteria-Synechococcus, Prochlorococcus - and small picoeukaryotes). This would result in a relatively lower transfer of heterotrophic bacterial carbon through grazers to other trophic levels (e.g., Fahnenstiel et al. 1991, Peters et al. 1998, Caron et al. 1999). In addition to the factors mentioned above, it has been suggested that grazers prefer live or 'active' bacteria (Landry et al. 1991, del Giorgio et al. 1996a, Christoffersen et al. 1997). Either because larger bacteria tend to be more active (Gasol et al. 1995) or simply for mechanical reasons, cell volume seems to be an important factor determining the probability of bacterial carbon being used by predators (Sherr et al. 1992). Larger bacteria are the most actively grazed (González et al. 1990, Monger \& Landry 1991, 1992), with the well-known exception of grazing-resistant morphologies (such as filaments or flocs; Jürgens \& Güde 1994).

Given that neither all bacteria nor all flagellates interact to the same degree, we should find a more detailed description within each microbial community, trying to separate, for instance, different bacterial components based on their relative degree of activity. Thus, del Giorgio et al. (1996a) used this approach to distinguish metabolically active bacteria (by using the CTC method) from inactive ones. They also found that grazing losses were more conspicuous in the former group. However, this technique is highly time consuming and has been questioned because of toxicity of the probe (Ullich et al. 1996).

The development of new methodologies that involve physiological probes and flow cytometry has allowed us to distinguish easily between bacterial types with different degrees of activity and to understand better each subfunction and activity rate. For example, we can now differentiate by flow cytometry 2 groups of bacteria based on cell-specific DNA staining. Building on the initial work of Li et al. (1995) we have proposed distinguishing on the one hand a high DNA group (HighDNA bacteria), which is assumed to correspond to the active fraction of the bacterial assemblage, and on the other hand a low DNA group (LowDNA bacteria), which is assumed to correspond to the dead or inactive bacteria (Gasol et al. 1999, Gasol \& del Giorgio 2000). Several lines of evidence indicate that HighDNA bacteria are the active fraction of the bacterial assemblage: the abundance of HighDNA bacteria corresponds to that of nucleoid-containing cells (Zweifel \& Hagström 1995) and to that of membrane-intact cells (Gasol et al. 1999). Recently, we have found a good correlation between the amounts of HighDNA bacteria and the number of cells that hybridize with a universal eubacterial rRNA probe. Furthermore, Servais et al. (1999) have shown that the bacteria with higher DNA content and higher cell light scatter have several times higher specific leucine uptake rates than the bacteria with lower DNA content or lower light scatter. Those with higher DNA content are also responsible for most of the total leucine uptake based on cell-sorting after leucine uptake experiments (Lebaron et al. 2001). In addition, Gasol \& Morán (1999) showed that 0.22 to $1.2 \mu \mathrm{m}$ filters retained HighDNA bacteria more effectively than the LowDNA bacteria, suggesting that they had a higher cell volume. All these studies, therefore, indicate that the active bacterial fraction tends to have a higher cellular volume and higher DNA and RNA content. Indirect evidence also indicates that grazing on bacteria is mainly on the HighDNA bacteria (Gasol et al. 1999, E. Sintes \& P. A. del Giorgio pers. comm.). This agrees with the fact that the HighDNA bacteria have all the properties (activity, size, etc) suggested to be selected by bacterial consumers. Hence, if the HighDNA bacterial fraction is the active part of the bacterial assemblage, we hypothesize that the dynamics of bacterial production (BP) and grazing losses should be closely related to the changes in HighDNA bacteria, rather than to changes in the whole bacterial community.

To test our hypothesis, we performed 12 grazing experiments during a cruise in the NW Mediterranean Sea along 2 transects from the coast to the open sea (3 stations in each transect, 2 depths at each station). First, we compared total grazing rates, BP and abundance of different bacterial groups in situ for the 12 natural environments. Afterwards, we surveyed changes in bacterial assemblages enclosed in experimental bottles for $44 \mathrm{~h}$. In each experimental bottle we followed bacterial abundance and biomass (total, HighDNA and LowDNA bacteria), cell volume, BP and bacterial grazing losses at different time intervals. Grazing rates on bacteria are usually obtained by following the increase of tracers inside the digestive vacuoles of predators in very short time intervals or by 
following the disappearance of fluorescent-labeled bacteria (FLB) through relatively long time intervals. In this study we decided to measure grazing rates on bacteria following the disappearance of FLB every 8 to $12 \mathrm{~h}$ for a total period of $44 \mathrm{~h}$. This allowed us to carefully observe changes in the growth and loss rate dynamics of the different bacterial subgroups within relatively short time intervals. Subsequently, we evaluated whether the changes in BP and grazing rates on bacteria are related more to the dynamics of HighDNA bacteria than to those of the whole bacterial community.

\section{MATERIAL AND METHODS}

Sampling. A cruise was carried out in the NW Mediterranean Sea (NE Iberian Peninsula) in March 1999 on board RV 'Garcia del Cid'. Water for the measurements and experiments was collected from 6 stations located in 2 transects and from 2 depths at each station. One of the transects runs offshore perpendicular to the city of Barcelona and the other to the city of Palamós. In each transect we sampled a station over the continental platform (the coastal station), a station on the shelf-slope front (the slope station) and a station over depths $>2000 \mathrm{~m}$ (the open-sea station; Fig. 1). Depth profiles of temperature, salinity and fluorescence were obtained with a Mark III CTD probe. Seawater was collected with 12 l Niskin bottles using a rosette attached to the Mark III CTD probe. The 2 depths chosen were surface $(5 \mathrm{~m})$ and the depth at which we detected an increase in fluorescence in the CTD profiles (depths varying from 20 to $40 \mathrm{~m}$ ). To confirm that the increase of fluorescence was due to chlorophyll a ( $\mathrm{chl} \mathrm{a}$ ) concentration we measured it. To this end, $100 \mathrm{ml}$ samples were filtered through Whatman GF/F filters and immediately frozen at $-70^{\circ} \mathrm{C}_{i}$ the filters were then left for $12 \mathrm{~h}$ in $90 \%$ acetone at $4^{\circ} \mathrm{C}$ in the dark for pigment extraction. Finally, chl a concentration was determined from the fluorescence of the acetone extracts with a Turner Designs 10-AV (Sunnyvale, CA, USA) fluorometer (Yentsch \& Menzel 1963).

Bacterivory. Five liter carboys were filled with 31 of seawater collected from each station and depth, and filtered through a mesh net of $50 \mu \mathrm{m}$ to avoid large predators other than protozoa (e.g., naupliae). One liter was kept in a $1.5 \mathrm{l}$ plastic bottle and immediately fixed with acidic lugol (1\% final concentration) to determine abundance and biomass of ciliates. The other 2 1 was inoculated with FLB: Pseudomonas diminuta (strain obtained from the Spanish Type Culture Collection, Burjassot, València) at 20 to $30 \%$ of the natural bacterial concentration. $P$. diminuta was previously heat-killed and stained with 5-([4,6 dichlorotriazin2yl) amino]-fluorescein (DTAF) (Vazquez-Dominguez et al. 1999). Duplicate 1.51 bottles were filled with 11 of seawater previously inoculated with the DTAF-stained $P$. diminuta. The bottles were incubated in an on-deck water bath with permanently flowing seawater to mimic in situ temperature $\left(12\right.$ to $\left.13^{\circ} \mathrm{C}\right)$. The bottles of each depth were covered with different types of screen to simulate the in situ light irradiance. This was determined using a Li-Cor spherical quantum sensor (Li-Cor Inc., Lincoln, NB, USA). To measure the different variables, subsamples from each duplicate bottle were taken for $44 \mathrm{~h}$ at different time intervals 8 and $12 \mathrm{~h}$ apart (samples were taken at 0, 8, 20,32 and $44 \mathrm{~h}$ ). At each time point, we measured bacterial abundance and estimated cell size, biomass and ${ }^{3} \mathrm{H}$-leucine incorporation, and abundance of DTAF-stained P. diminuta. At time 0 we also collected subsamples to determine abundance and biomass of HNFs. Additionally, from the Barcelona coastal station (Fig. 1) we collected an extra 61 water sample. Three liters was filtered through $0.8 \mu \mathrm{m}$, and the other 3 through $0.2 \mu \mathrm{m}$ polycarbonate filters. We filled six 1.51 plastic bottles with this filtered water. Triplicate bottles for the 0.8 and $0.2 \mu \mathrm{m}$ fraction were inoculated with DTAF-stained $P$. diminuta (at $20 \%$ of the natural bacterial concentration) to be used as live controls. Usually this is done by inoculating fluorescent tracers in $0.8 \mu \mathrm{m}$ filtered seawater. However, because some HNF can pass through $0.8 \mu \mathrm{m}$, we also used seawater filtered by $0.2 \mu \mathrm{m}$ just to make sure that disappearance of stained $P$. diminuta

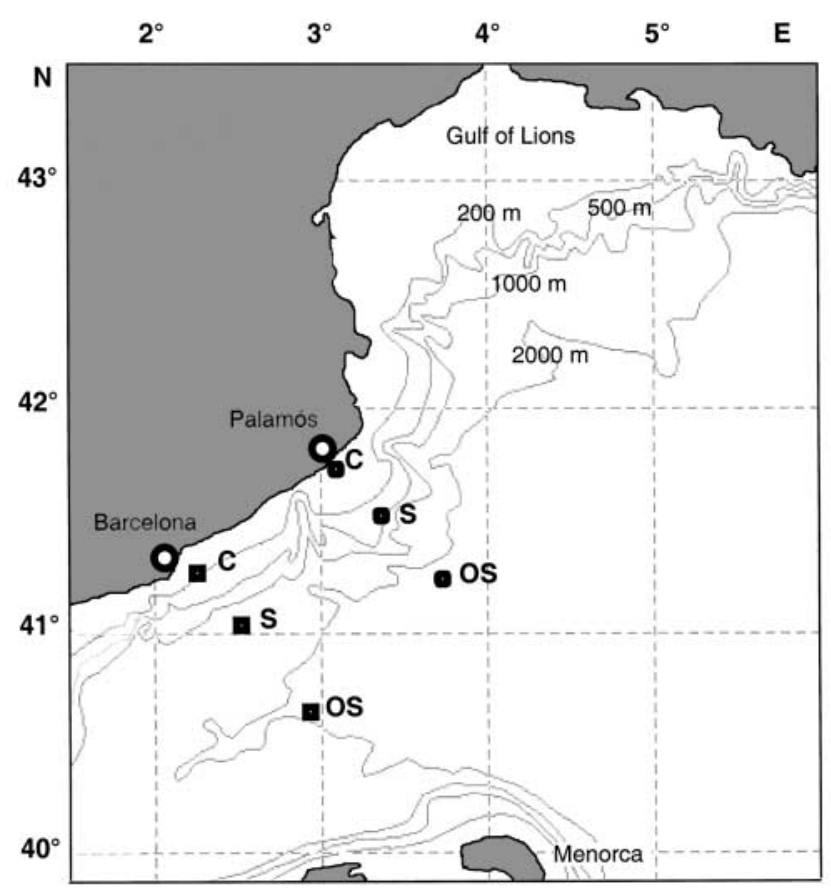

Fig. 1. Map of the area sampled showing locations of transects and stations. C: coastal; S: slope; OS: open-sea stations 
was due to grazing and not to losses of fluorescence or FLB attachment to the bottle walls. DTAF-stained $P$. diminuta were counted using flow cytometry (see below) for every interval time and by epifluorescence microscopy at the initial and final times.

Calculation of grazing rates on bacteria: Bacterivory was determined following the disappearance of Pseudomonas diminuta over time according to the methods described by Vazquez-Dominguez et al. (1999). The amount of consumed bacteria was obtained following the mathematical model of Salat \& Marrasé (1994), first computing specific grazing rate at any selected time $(g)$ :

$$
g=-(1 / t) \times \ln \left(P d i_{t} / P d i_{0}\right)
$$

where $t$ is incubation time, $P d i_{t}$ is the number of $P$. diminuta at each considered time and $P d i_{0}$ is the number of $P$. diminuta at the initial time considered.

Next, net bacterial growth rate at any selected time (a) was calculated as follows:

$$
a=(1 / t) \times \ln \left(B N_{t} / B N_{0}\right)
$$

where $t$ is incubation time, $B N_{t}$ is bacterial number at each considered time of the experiment and $B N_{0}$ is bacterial number at the initial time considered. Finally, total grazing time $(G)$ was calculated:

$$
G=(g / a) \times \Delta B_{\mathrm{i}}
$$

where total grazing is measured as bacteria consumed $\mathrm{ml}^{-1}$ time $^{-1}$ and $\Delta B_{\mathrm{i}}$ is net bacterial increase at each determined time. For each interval time, grazing rates of bacteria were unified as bacteria consumed $\mathrm{ml}^{-1} \mathrm{~d}^{-1}$.

Bacterial, Pseudomonas diminuta, HNF and ciliate abundances, cell volume and biomass. At the beginning and at the end of the incubations, we collected aliquots to determine bacterial and Pseudomonas diminuta abundance by both epifluorescence microscopy (Porter \& Feig 1980) and flow cytometry (del Giorgio et al. 1996b, Vazquez-Dominguez et al. 1999, Gasol \& del Giorgio 2000). Some counts of bacteria and $P$. diminuta were duplicated using both techniques at 0 and at $44 \mathrm{~h}$ to be sure that the flow cytometry counts were reliable. HNFs (abundance and cell size) were determined only at time 0 by epifluorescence microscopy.

From each duplicate, $100 \mathrm{ml}$ aliquots were preserved with glutaraldehyde ( $1 \%$ final concentration), and 10 to $20 \mathrm{ml}$ was used for bacterioplankton and Pseudomonas diminuta counts, and 20 to $30 \mathrm{ml}$ for nanoflagellate counts. They were filtered through 0.2 and $0.6 \mu \mathrm{m}$ polycarbonate filters, respectively, and stained with DAPI (Porter \& Feig 1980) at a final concentration of $5 \mu \mathrm{g} \mathrm{ml}^{-1}$ (Sieracki et al. 1985). Abundance of these microorganisms was determined using an OlympusBX40-102/E epifluorescence microscope (Olympus
Optical Co., Hamburg, Germany) at 1000× magnification. Bacteria were observed and counted using the UV filter, while DTAF-stained $P$. diminuta were determined using a B2 filter (blue light) with a yellow-green fluorescence. Between 200 and 300 cells filter $^{-1}$ were counted. DTAF-stained $P$. diminuta size was measured with the image analysis system described by Massana et al. (1997). P. diminuta are small bacilar cells of around $1.07 \mu \mathrm{m}$ length and $0.29 \mu \mathrm{m}$ width, with a volume of $\sim 0.065 \mathrm{\mu m}^{3} \mathrm{cell}^{-1}$.

HNFs and phototrophic nanoflagellates were observed under both UV light (blue fluorescence) and blue light (B2 filter). Under blue light we could discriminate phototrophic nanoflagellates (showing redorange fluorescence or plastidic structures) from colorless nanoflagellates enumerated as heterotrophic (HNF). With this method we could not distinguish mixotrophic nanoflagellates. Between 100 and 200 cells filter $^{-1}$ were counted. Nanoflagellate size was determined by measuring lengths and widths of all cells counted with a calibrated micrometric eyepiece. Cell volumes were estimated by assigning each cell to the nearest geometrical figure. Carbon content was estimated using the volume to carbon factor of $0.22 \mathrm{pg}$ $\mathrm{C} \mu \mathrm{m}^{-3}$ (Børsheim \& Bratbak 1987).

Flow cytometry: From each sample, $1.2 \mathrm{ml}$ aliquots were fixed immediately with freshly prepared $1 \%$ paraformaldehyde plus $0.05 \%$ glutaraldehyde (final concentration), incubated for $10 \mathrm{~min}$ at room temperature and then stored frozen in liquid nitrogen. Aliquots were divided into 2 fractions for counts of bacteria and DTAF-stained Psuedomonas diminuta. To count heterotrophic bacteria, $200 \mu \mathrm{l}$ was stained with a DMSdiluted SYTO-13 (Molecular Probes Inc., Eugene, OR, USA) stock (10:1) at $2.5 \mu \mathrm{M}$ final concentration, left for $\sim 10$ min in the dark to complete the staining and run in a flow cytometer. We used a Becton Dickinson FACScalibur bench cytometer (BD Bioscience, Franklin Lakes, NJ, USA) with a laser emitting at $488 \mathrm{~nm}$. Samples were run at low speed, and data were acquired in log mode until around 10000 events had been acquired. We were careful to maintain the rate of particle passage below 300 events $\mathrm{s}^{-1}$ by diluting the sample, if necessary, with sheath fluid (Milli-Q water in this case) to avoid coincidence. We added $10 \mu \mathrm{l} \mathrm{sam-}$ $\mathrm{ple}^{-1}$ of a solution of yellow-green $1 \mu \mathrm{m}$ latex beads $\left(10^{6}\right.$ beads $\left.\mathrm{ml}^{-1}\right)$ as an internal standard (Polysciences, Inc., Warrington, PA, USA). The bead solution was counted daily, and the counts were cross-calibrated with the concentration obtained from the rate of particle passage and the time of sample passage (Gasol \& del Giorgio 2000). Bacteria were detected by their signatures in a plot of $90^{\circ}$ light scatter (SSC) versus green fluorescence (FL1). We separated HighDNA bacteria from LowDNA bacteria in the SSC versus FL1 plot 
(Gasol et al. 1999). Cytometric noise (that is, particles that cannot be assigned to any population but that appear close to the position of the population) at times interfere with the determination of LowDNA bacteria. This noise can be either electronic or due to the fixative not being fresh. After delimiting the bacterial population in the SSC versus FL1 (red fluorescence) plot, we separated cells from electronic noise in the FL1 versus FL3 plot. In such a plot the bacterial cells, both HighDNA and LowDNA, remain in a diagonal line while the beads are placed in a parallel diagonal and noise in another parallel line (Gasol \& del Giorgio 2000). For DTAF-stained $P$. diminuta counts, we took $200 \mu \mathrm{l}$ and, as for heterotrophic bacteria, we added $10 \mu \mathrm{l} \mathrm{sample}^{-1}$ of a solution of yellow-green $1 \mu \mathrm{m}$ Polysciences latex beads $\left(10^{6}\right.$ beads $\left.\mathrm{ml}^{-1}\right)$ as an internal standard. In this case it was not necessary to add any dye. We followed the same cytometric procedure as for bacteria. DTAFstained $P$. diminuta were detected by their signatures in a plot of $90^{\circ}$ light scatter (SSC) versus FL1. Bacterial cell size was estimated using the relation between average bacterial size, obtained by image analysis of DAPI preparations following common procedures and average fluorescence of the SYTO-13 stained sample relative to beads (Gasol \& del Giorgio 2000):

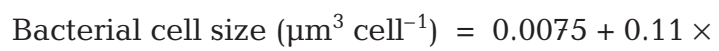
(FL1 bacteria/FL1 beads)

Bacterial biomass was calculated by using the carbon to volume relation derived by Norland (1993) from the data of Simon \& Azam (1989):

Bacterial biomass $\left(\mathrm{pg} \mathrm{C}\right.$ cell $\left.{ }^{-1}\right)=0.12 \mathrm{pg} \times\left(\mu^{3} \text { cell }^{-1}\right)^{0.7}$

Inverted microscopy: Ciliate abundance and biomass were examined in single 11 samples that were preserved in a $1 \%$ final concentration of acidic Lugol (Sigma Chemical Co., St. Louis, MO, USA). Samples $(100 \mathrm{ml})$ were settled for $48 \mathrm{~h}$. Ciliates were observed and enumerated using an inverted microscope (Axiovert 35, Zeiss, Germany) at 400× magnification. Average ciliate size was determined after measuring all cells recorded sample ${ }^{-1}$ (between 50 and 100 cells). Ciliate volume was measured by assigning each cell to the nearest geometric shape. The average cell volume of each identified group was converted to carbon equivalents using the factor experimentally derived for

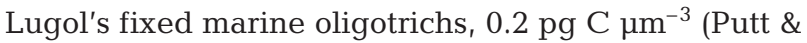
Stoecker 1989). Carbon weight for tintinnids was estimated using the experimentally determined factor of 0.053 pg $C \mathrm{~m}^{-3}$ (Verity \& Langdon 1984).

Bacterial activity and production. We estimated bacterial activity as the rate of radioactive leucine incorporation by bacteria, using the method described by Kirchman (1993) but in Eppendorf vials as suggested by Smith \& Azam (1992). For each duplicate sample, we added $40 \mathrm{nM}$ leucine to triplicate vials plus 1 TCA-killed control. BP was calculated from leucine incorporation according to the following equation:

$$
B P=\mathrm{leu} \times \mathrm{CF}
$$

where $\mathrm{CF}$ is the conversion factor expressed in $\mathrm{kg} \mathrm{C}$ $\mathrm{mol}^{-1}$. We used the conversion factors obtained for the coastal, slope and open-sea stations in the NW Mediterranean on a cruise similar to the one reported here, as described by Pedrós-Alió et al. (1999). We used the same factor for the surface and at the deep chlorophyll maximum depths: coastal station,: $2.01 \mathrm{~kg}$ $\mathrm{C} \mathrm{mol}^{-1}$ leucine; slope station, $1.54 \mathrm{~kg} \mathrm{C} \mathrm{mol}^{-1}$; and

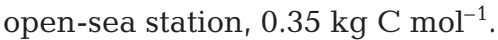

From these estimates of production, specific growth rates $(\mu)$ were calculated as follows:

$$
\mu=\ln (1+B P / B B) / t
$$

where $B B$ is bacterioplankton biomass and $t$ is the time over which production is considered.

Data analysis. All variables (bacterial abundance, biomass and production), except the percentage of HighDNA (\%HighDNA) bacteria, were $\log _{10}$ transformed to equalize variance. The relations between biological variables were examined by means of regression and correlation analysis computing Pearson pairwise statistics. Differences in biological variables over time periods ( 0 to $44 \mathrm{~h}$ ) were tested by ANOVA analysis. Post-hoc Tukey tests were performed to confirm differences between time intervals $(0,8,20,32$ and $44 \mathrm{~h})$.

\section{RESULTS}

\section{Methodological considerations}

Flow cytometry versus epifluorescence counts

Flow cytometric counts of total bacteria (log flow cytometric counts of bacteria $=-0.0286+1.00 \times \log$ epifluorescence counts of bacteria, $\mathrm{n}=46, \mathrm{R}^{2}=0.872$, $\mathrm{p} \leq 0.0001$ ) and DTAF-stained Pseudomonas diminuta (log flow cytometric counts of $P$. diminuta $=0.319+$ $0.939 \times \log$ epifluorescence counts of $P$. diminuta, $\mathrm{n}=$ $40, \mathrm{R}^{2}=0.630, \mathrm{p}=0.001$ ) were well correlated with microscopic counts, with slopes very close to 1 .

\section{Evolution of Pseudomonas diminuta disappearance}

Fig. 2A shows an example of the changes of Pseudomonas diminuta abundance with time for coastal samples in the Barcelona transect, at $5 \mathrm{~m}$. Disappearance of $P$. diminuta followed an exponential 


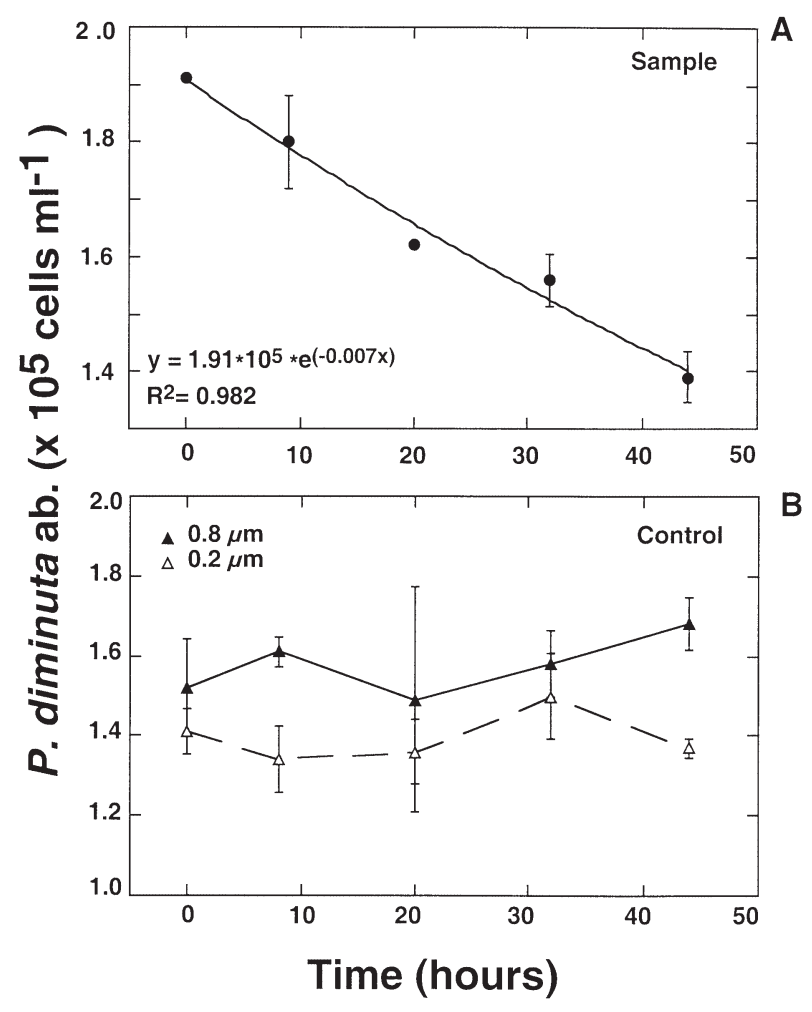

Fig. 2. Evolution of 5-([4,6 dichlorotriazin-2yl) amino]-fluorescein (DTAF)-stained Pseudomonas diminuta through time in 'natural' and control samples. (A) Intact Barcelona transect coastal water from $5 \mathrm{~m}_{\text {; }}$ (B) filtered $(0.2$ and $0.8 \mu \mathrm{m})$

Barcelona coastal water from $5 \mathrm{~m}$. Bars represent SD

model as expected (Salat \& Marrasé 1994); however, consumption was not observed between all time intervals (e.g., 20 to $32 \mathrm{~h}$ ). This very low or not significant $P$. diminuta disappearance at some time intervals also appeared in the other experiments (see Fig. 4 below).

\section{Evolution of Pseudomonas diminuta in the control}

To be sure that the disappearance of Pseudomonas diminuta was entirely due to grazers and not to artifacts, we ran a control sample without predators in parallel to the experimental sample (Fig. 2B). This sample was collected at the Barcelona coastal station at $5 \mathrm{~m}$ and filtered through 0.8 and $0.2 \mu \mathrm{m}$ filters (Fig. 2B). In the experimental sample we observed clear differences between most of the time intervals (Fig. 2A; ANOVA: $\mathrm{n}=10, F=17.39, \mathrm{p}=0.0039$ ). For the control samples there were no differences between time intervals (Fig. 2B; ANOVA for the $0.2 \mu \mathrm{m}$ filtered sample: $\mathrm{n}=15, F=1.36, \mathrm{p}=0.446$; ANOVA for the $0.8 \mu \mathrm{m}$ filtered sample: $\mathrm{n}=15, F=0.436, \mathrm{p}=0.846)$. These results confirm that the disappearance of DTAFstained $P$. diminuta was due to the grazers' impact.

\section{In situ values and total bacterivory rates}

In late winter (March 1999), the water temperature was almost uniform throughout the entire water column and ranged between 12.4 and $13.1^{\circ} \mathrm{C}$ (Table 1). Chl a concentrations were in general higher in the Palamós transect than in the Barcelona transect, but similar at the 2 depths of interest except at the Barcelona coastal station (Table 1). Bacterial abundance varied from $1.5 \times 10^{5}$ cells $\mathrm{ml}^{-1}$ at the open-sea station of the Barcelona transect to $8.9 \times 10^{5} \mathrm{cells} \mathrm{m}^{-1}$ at the open-sea station of the Palamós transect (Table 1). $\%$ HighDNA bacteria, bacterial growth rates $(\mu)$, BP and estimated average cell size reached minimum and maximum values in Palamós stations (open sea and slope, respectively; Table 1). The \%HighDNA bacteria ranged from 25.2 to $87.1 \%$, and BP varied from 0.09 to $5.9 \mu \mathrm{g} \mathrm{Cl}^{-1} \mathrm{~d}^{-1}$. We found a significant relation between BP and both \%HighDNA and HighDNA bacterial abundance (Fig. 3A,B). No relations were found between BP and total $(\mathrm{n}=12, \mathrm{R}=0.047, \mathrm{p}=0.885)$ and LowDNA bacterial abundance (Fig. 3B). Total bacterivory rates (cells $\mathrm{ml}^{-1} \mathrm{~d}^{-1}$ ), as computed between 0 and $44 \mathrm{~h}$, varied 1 order of magnitude, from $0.2 \times 10^{5}$ (Palamós transect, open-sea station) to $2.2 \times 10^{5}$ cells $\mathrm{ml}^{-1} \mathrm{~d}^{-1}$ (Palamós coastal station; Table 1). A borderline significant relation was encountered between total grazing rates and \%HighDNA-bacteria ( $\mathrm{n}=12, \mathrm{R}=$ 0.570, $\mathrm{p}=0.050$; Fig. 3C), and a more significant one between total grazing and $\mathrm{BP}(\mathrm{n}=12, \mathrm{R}=0.742, \mathrm{p}=$ 0.006; Fig. 3D). Furthermore, total grazing rates correlated with total bacteria $(\mathrm{n}=11, \mathrm{R}=0.690, \mathrm{p}=0.017$ ) and were even more related to HighDNA bacterial abundance $(\mathrm{n}=11, \mathrm{R}=0.744, \mathrm{p}=0.009$; Fig. 3E) when the value for the open-sea station of the Palamós transect $(5 \mathrm{~m})$ was excluded. This station showed different characteristics from the others (see next section). No relation was detected between LowDNA bacteria and grazing rates $(n=11, p=0.361$; Fig. 3E), regardless of whether the open-sea Palamós station was included. Consequently, these results indicate that BP and consumption rates were higher in those stations where there were more HighDNA bacteria.

HNF and ciliates were more abundant in the Palamós transect and less abundant in the Barcelona transect (Table 1). HNF cell volume ranged from 7.7 (Barcelona open-sea) to $27.4 \mu^{3}$ cell $^{-1}$ (Palamós opensea; Table 1). In addition, higher HNF cell sizes and biomasses were recorded in the Palamós transect (mean $7.25 \pm 2.9 \mu \mathrm{g} \mathrm{C}^{-1}$ ) than in the Barcelona tran-

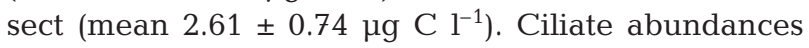
followed a similar pattern between stations to that of HNF abundances (Table 1) and a significant correlation was found between HNF and ciliate abundance ( $\mathrm{n}=12, \mathrm{R}=0.663, \mathrm{p}=0.02)$. Ciliate cell size ranged 


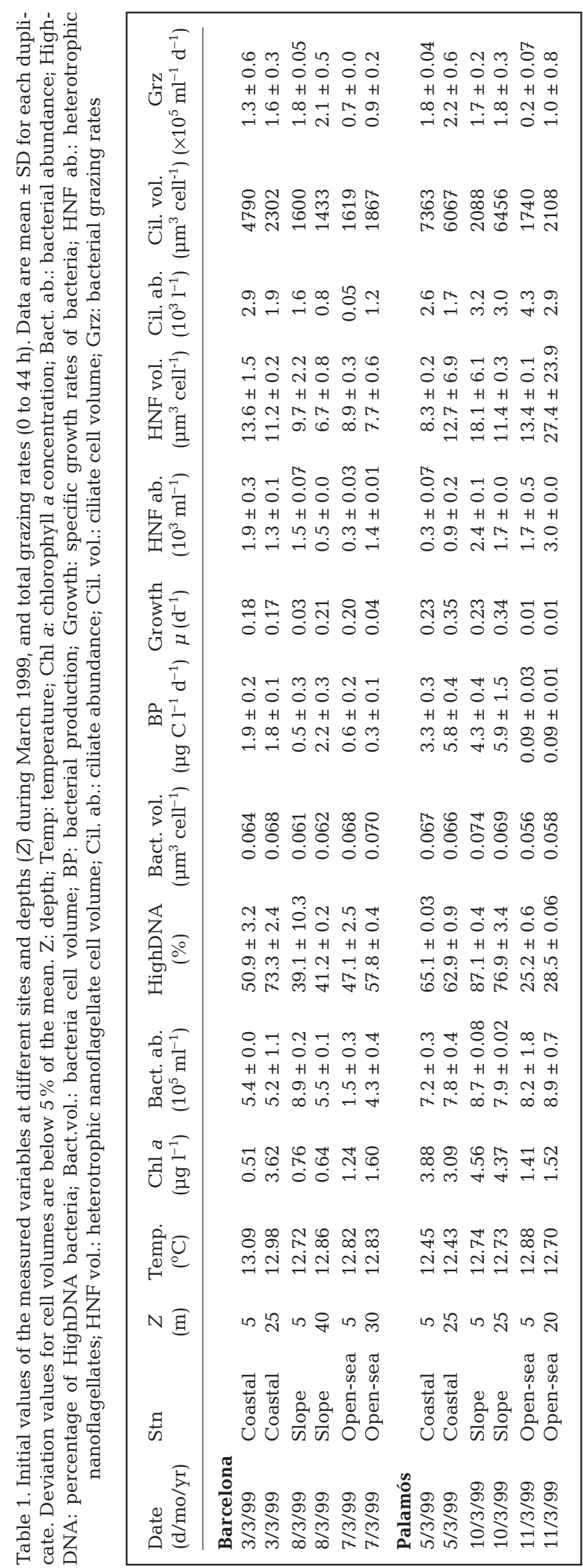

from 1433 to $7363 \mu^{3}$ cell $^{-1}$, the lowest and largest cell volume being recorded at the slope (Barcelona transect) and coastal (Palamós transect) stations, respectively. As for HNF, higher ciliate cell sizes and biomasses were recorded in the Palamós transect $(2.29 \pm$ $\left.0.49 \mu \mathrm{g} \mathrm{C} \mathrm{l}^{-1}\right)$ than in the Barcelona transect $(0.82 \pm$ $0.42 \mu \mathrm{g} \mathrm{C} \mathrm{l}^{-1}$ ). Naked oligotrichs dominated ciliate communities. For instance, Strombidium (mean percentage contribution, $44 \pm 15.6 \%$ ) and Strobilidium (mean $46 \pm 17.9 \%$ ) dominated in the Barcelona transect, while in the Palamós transect Strobilidium (mean percentage contribution $52 \pm 6.9 \%$ ) was the most abundant genus, followed by Strombidium (mean $22.3 \pm 15.8 \%$ ) and Tontonia (mean19 $\pm 14.8 \%$ ).

HNF abundance was well correlated with total bacterial abundance but not to HighDNA bacterial abundance (Table 2). When each transect was analyzed separately, the correlation between HighDNA bacteria and HNF abundance was higher than that between total bacteria and HNF abundances in the Barcelona transect. In contrast, a high correlation between total bacteria and HNF abundance was found in the Palamós transect, while no correlation was observed between HNF abundance and HighDNA bacterial abundance in that transect (Table 2).

\section{A close look at what occurs inside the experimental bottles}

\section{Changes in bacterial abundance, biomass BP and grazing}

In all experiments, very small changes in LowDNA bacterial abundances were observed, never exceeding a 2 -fold increase. HighDNA bacterial abundance, however, showed maximum increases of up to 8-fold (e.g., at slope station of the Barcelona transect at $40 \mathrm{~m}$, from $0.2 \times 10^{6}$ at time 0 to $1.6 \times 10^{6} \mathrm{cell} \mathrm{ml}^{-1}$ at time 20 h). Fig. 4 shows some representative examples of the evolution over time of the studied variables in each experimental bottle. We found 3 major patterns in the changes of HighDNA bacterial biomass, bacterivory, $\%$ HighDNA bacteria and BP.

(1) At coastal stations (in both the Barcelona and the Palamós transects) we found that HighDNA bacteria (percentage and biomass) and BP, after $8 \mathrm{~h}$, increased toward the end of the experiment, achieving an exponential growth between 20 and $32 \mathrm{~h}$ (Fig. 4A,B). Disappearance of Pseudomonas diminuta was roughly constant over time up to $20 \mathrm{~h}$. Simultaneously with the bacterial exponential growth (20 to $32 \mathrm{~h}$ ), minimal tracer disappearance occurred. Finally, between 32 and $44 \mathrm{~h}$ the greatest consumption of $P$. diminuta paralleled the maximum values of HighDNA bacteria 

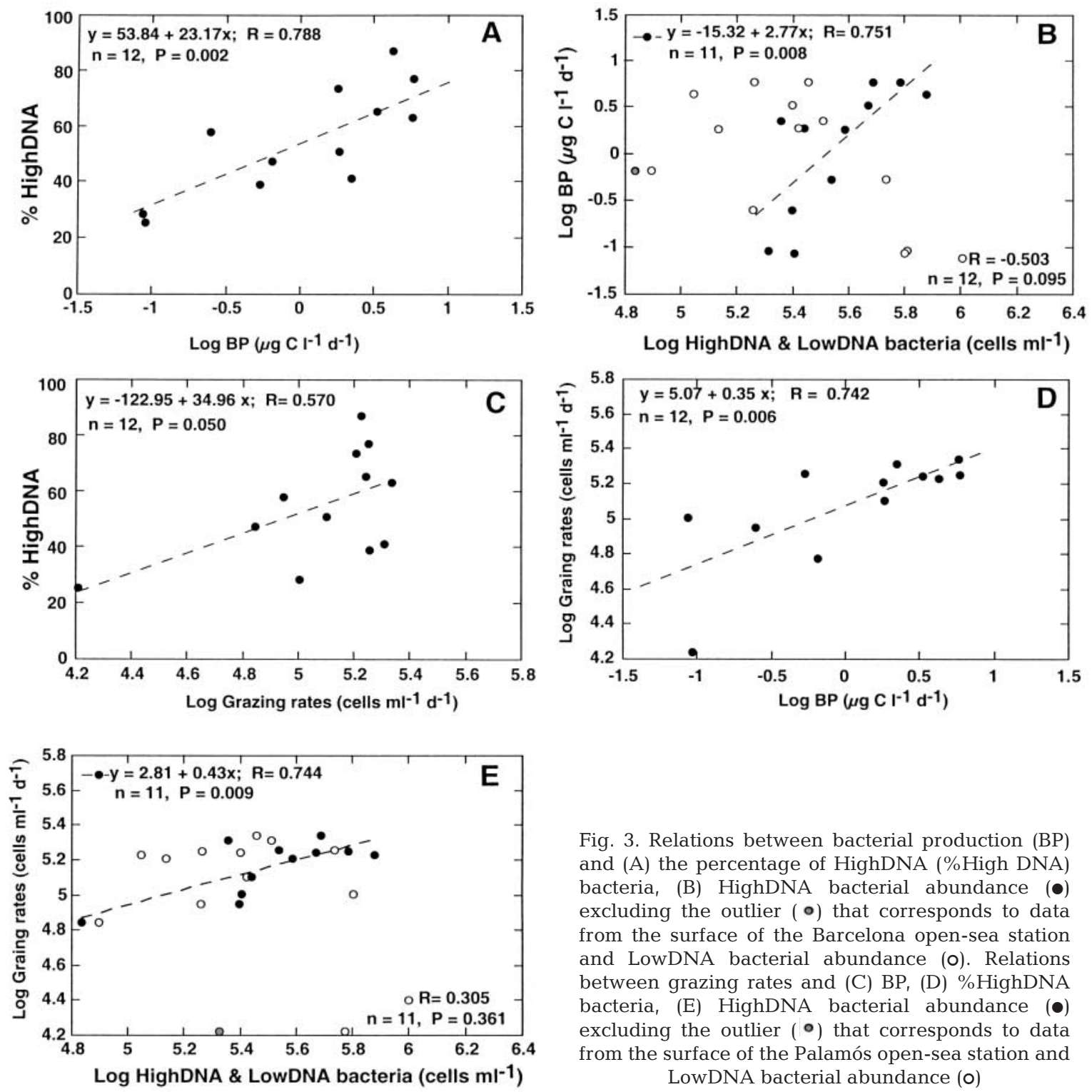

Fig. 3. Relations between bacterial production (BP) and (A) the percentage of HighDNA (\%High DNA) bacteria, (B) HighDNA bacterial abundance (•) excluding the outlier $(\bullet)$ that corresponds to data from the surface of the Barcelona open-sea station and LowDNA bacterial abundance (o). Relations between grazing rates and (C) BP, (D) \%HighDNA bacteria, (E) HighDNA bacterial abundance (•) excluding the outlier $(\bullet)$ that corresponds to data from the surface of the Palamós open-sea station and LowDNA bacterial abundance (o)

(percentage and biomass) and BP. Comparing BP and grazing losses ( $\mu \mathrm{g} \mathrm{C} \mathrm{l}^{-1} \mathrm{~d}^{-1}$ ), we observed that production was always higher than grazing (Fig. 5A). Thus,

for the first ( 0 to $8 \mathrm{~h}$ ) and the second ( 8 to $20 \mathrm{~h}$ ) time intervals, the ratio between consumed bacterial carbon and BP was around 1.5. The maximum ratio (around $15 \times$ ) occurred when exponential

Table 2. Pearson pairwise correlation coefficients (R) between bacterial categories and HNF abundance obtained in each transect and all together

\begin{tabular}{|lccccccccccc|}
\hline & \multicolumn{3}{c}{ Barcelona } & \multicolumn{3}{c}{ Palamós } & \multicolumn{3}{c}{ All } \\
& $\mathrm{n}$ & $\mathrm{R}$ & $\mathrm{p}$ & $\mathrm{n}$ & $\mathrm{R}$ & $\mathrm{p}$ & $\mathrm{n}$ & $\mathrm{R}$ & $\mathrm{p}$ \\
\hline $\begin{array}{l}\text { Total bacterial } \\
\text { abund. }\end{array}$ & 6 & 0.763 & 0.050 & 6 & 0.903 & 0.014 & 12 & 0.594 & 0.041 \\
$\begin{array}{l}\text { HighDNA } \\
\text { bacterial abund. }\end{array}$ & 6 & 0.863 & 0.026 & 6 & -0.169 & 0.748 & 12 & 0.416 & 0.178 \\
$\begin{array}{l}\text { LowDNA } \\
\text { bacterial abund. }\end{array}$ & 6 & 0.523 & 0.286 & 6 & 0.124 & 0.816 & 12 & 0.341 & 0.271 \\
\hline
\end{tabular}
growth and almost no bacterial losses appeared (20 to $32 \mathrm{~h}$ ). In the final period, bacterial grazing losses reached their maximal value and the ratio was reduced to half (Fig. 5A).

(2) At the slope stations of both transects and at the open-sea station of the Barcelona transect we detected a slightly different pattern. In this case, HighDNA bacteria (biomass and percentage) and BP increased after $8 \mathrm{~h}$ until it reached a plateau at $32 \mathrm{~h}$ 

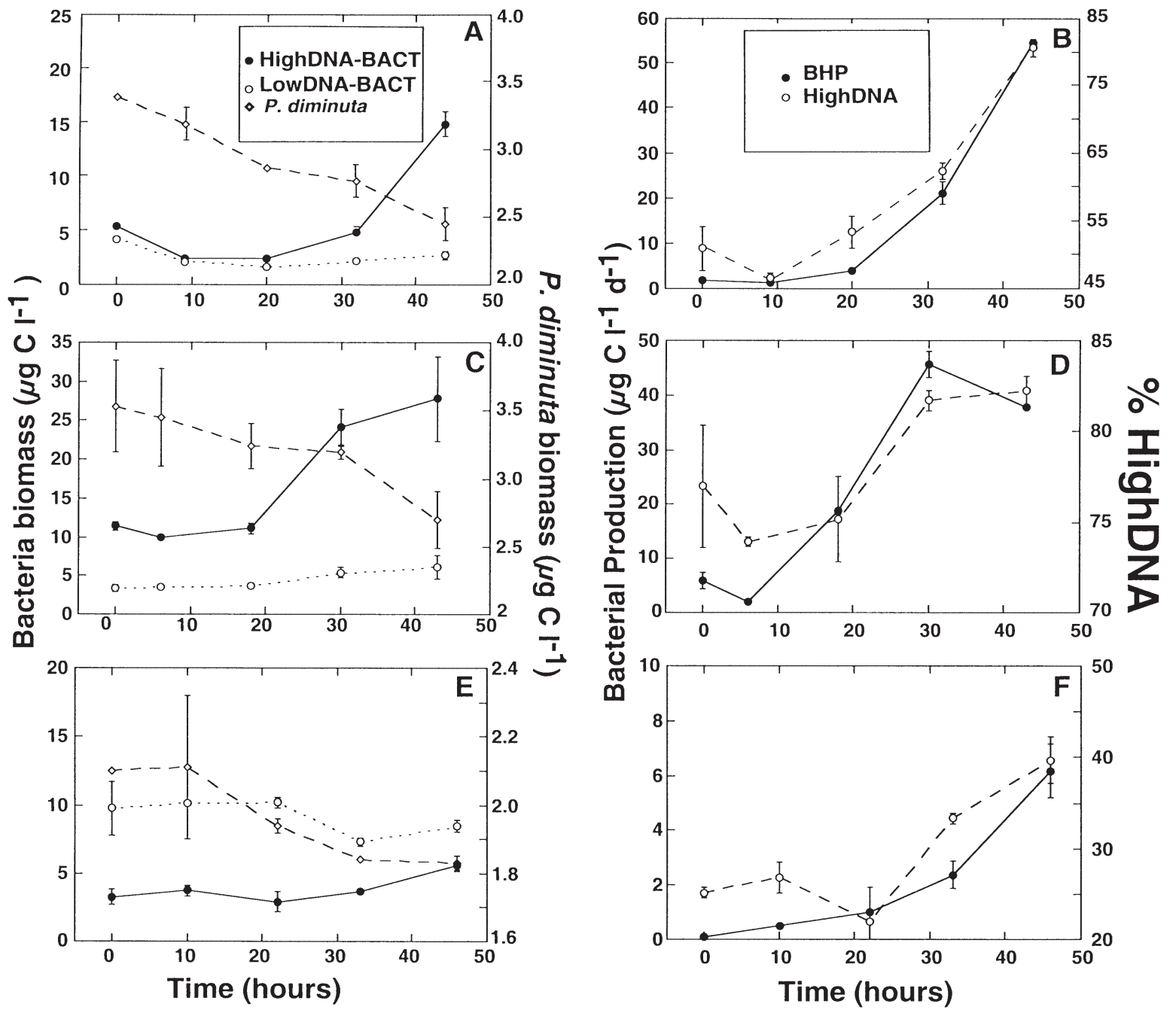

Fig. 4. Data from incubation samples. (A,C,E) Changes through time of HighDNA bacteria, LowDNA bacteria and Pseudomonas diminuta biomasses. $(\mathrm{B}, \mathrm{D}, \mathrm{F})$ Changes in bacterial production and \%HighDNA bacteria in several representative stations. Upper panels: coastal station of the Barcelona transect at $5 \mathrm{~m}$; center panels: slope station of the Palamós transect at $25 \mathrm{~m}$; lower panels: open-sea station of the Palamós transect at $5 \mathrm{~m}$. Bars represent SD

(Fig. 4C,D). Exponential growth occurred between 20 and $32 \mathrm{~h}$ and, as stated above, during this time interval disappearance of Pseudomonas diminuta was minimal (Fig. 4C,D). Finally, the greatest consumption occurred in the time interval between 32 and $44 \mathrm{~h}$, when BP and HighDNA (percentage and biomass) reached the plateau. Evolution of bacterial carbon grazed with respect to BP for each time interval showed a similar trend to that for coastal stations, although higher losses were detected at the end of the experiment (Fig. 5A,B). Hence, a lower carbon ratio (production to losses) than at the coastal stations was observed during the last period.

(3) The third pattern was identified at the open-sea station of the Palamós transect. This was the only station where the biomass of LowDNA bacteria was con- sistently higher than that of HighDNA bacteria (Fig. 4E). Indeed, BP and HighDNA bacteria (percentage and biomass) were also the lowest of all experiments (Fig. 4E,F). BP increased slowly toward the end of the experiment, starting to grow exponentially between 32 and $44 \mathrm{~h}$ (Fig. 4F). HighDNA bacteria (percentage and biomass) started to increase after $20 \mathrm{~h}$. Pseudomonas diminuta did not disappear until 10 to $20 \mathrm{~h}$ (Fig. 4E), $\sim 8 \mathrm{~h}$ later than in the cases mentioned above. Then, when bacterial exponential growth started (32 to $44 \mathrm{~h}$ ), the minimum disappearance of $P$. diminuta was detected (Fig. 4E). Thus, carbon losses were undetectable during the first interval period, and grazing pressure overcame production in the time interval 10 to $20 \mathrm{~h}$, coinciding with a decrease in \%HighDNA bacteria (Fig. 4F). Afterward, grazing 


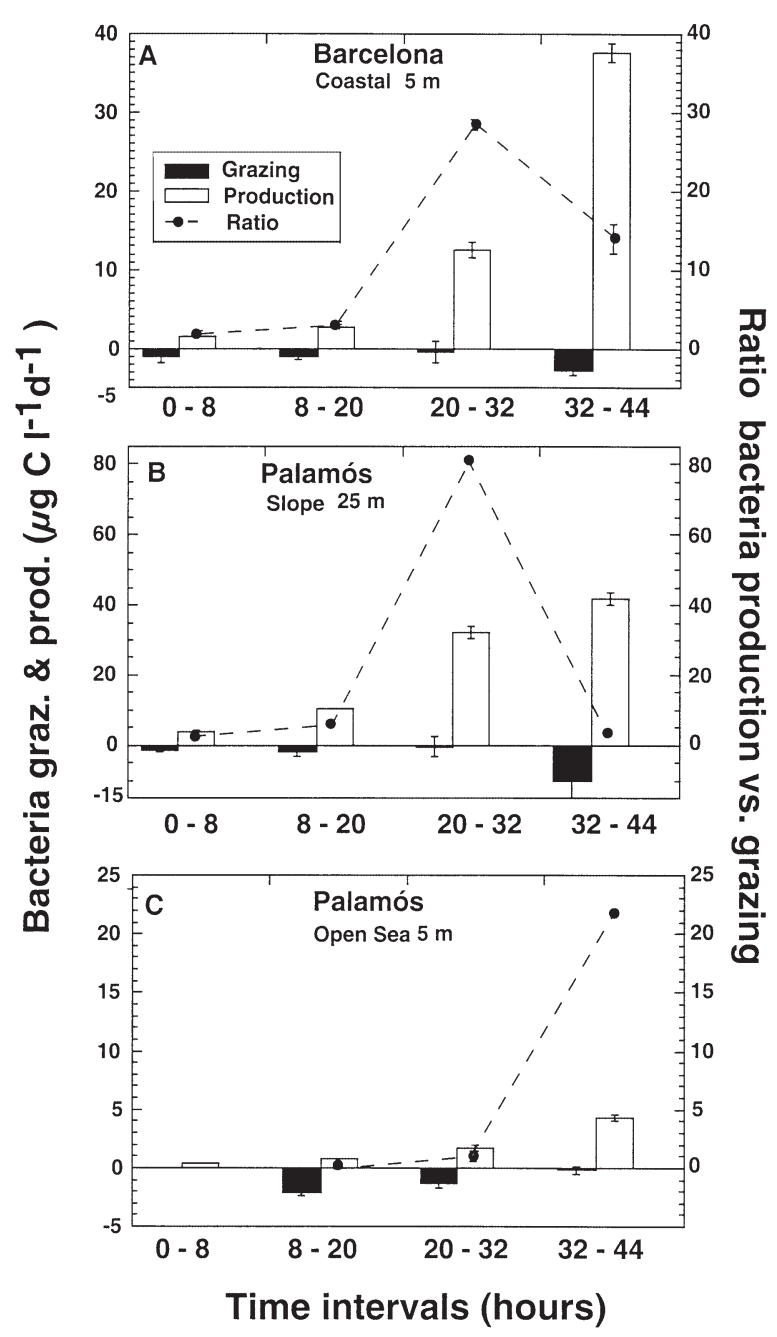

Fig. 5. Data from incubation samples. Bacterial production, grazing rates and production to grazing carbon ratios at several representative stations: coastal (A), slope (B) and open sea $(C)$. Bars represent $S D$

losses decreased to almost undetectable levels when bacteria reached their maximum growth rates. At this point the carbon ratio was maximal (Fig. 5C). It seems, therefore, that we should have waited at least another $12 \mathrm{~h}$ to obtain a similar trend to those observed at the other 2 stations.

Pooling the whole data set for bacterial abundance (including the individual points of all time periods), we observed a fairly regular pattern in all samples. Bacterial abundance was maintained at similar values from 0 to $20 \mathrm{~h}$, and increased at $32 \mathrm{~h}$ (Fig. 6A), this pattern being more conspicuous for HighDNA bacteria. For the whole period, constant values or small increases of between 32 and $44 \mathrm{~h}$ of LowDNA bacterial abundance were recorded (Fig. 6C). An increase in net bacterial growth rates from 8 to $32 \mathrm{~h}$ (Fig. 6D) translated into increases in HighDNA bacteria mainly at $32 \mathrm{~h}$
(Fig. 6B). The specific net growth recorded (Fig. 6D) was almost exclusively due to the HighDNA bacteria (Fig. 6B) that outgrew the grazing pressure. In spite of the great variability among stations, net bacterial growth rates and specific grazing rates (Fig. 6D,E) also showed a trend similar to that found for BP and total grazing rates, at least in 2 of the chosen examples (Fig. $5 \mathrm{~A}, \mathrm{~B})$. We observed a decrease in specific grazing rates between 20 and $32 \mathrm{~h}$, when bacteria were growing exponentially at the majority of stations.

\section{Relation between HighDNA bacteria and BP}

When we looked at the initial values (Table 1), we found a fairly strong correlation between BP and HighDNA bacterial abundance (Fig. 3). When we used all the data from the grazing experiments, BP was strongly related to HighDNA bacterial biomass, with a better relation than that with total bacterial biomass (Fig. 7A,B). LowDNA bacterial biomass and BP were not related at all (Fig. 7C). Consequently, the apparent relation between BP and total bacterial biomass is due mainly to the changes in HighDNA bacterial biomass.

\section{Relations between HighDNA bacteria and bacterivory}

When relating the abundance of bacteria present at $8,20,32$ and $44 \mathrm{~h}$ with total grazing rates (cell ml $\mathrm{ml}^{-1} \mathrm{~d}^{-1}$ ) for each period considered ( 0 to 8,8 to 20,20 to 32 and 32 to 44 ), we found a significant correlation ( $n=40, R=$ $0.416, p=0.008$ ). A more significant correlation was found between total grazing rates and HighDNA bacterial abundance ( $\mathrm{n}=40, \mathrm{R}=0.429, \mathrm{p}=0.006$ ), and no correlation at all was found with LowDNA bacterial abundance $(\mathrm{n}=40, \mathrm{R}=0.123, \mathrm{p}=0.449$ ). How could we have found this significant correlation if there was a decrease in bacterial grazing rates when the maximum growth of bacteria appeared (e.g., 20 to 32 h)? The answer is that the maximal values of total and HighDNA bacterial abundances or biomass were in general registered between 32 and $44 \mathrm{~h}$, at the time that coincided with the highest grazing losses.

\section{DISCUSSION}

The results presented indicated that samples from stations with higher proportions of HighDNA bacteria were also those with higher BP and grazing rates when we considered both the in situ values and the data from the experiments. Although these results might appear obvious, few or no studies have followed at short time 


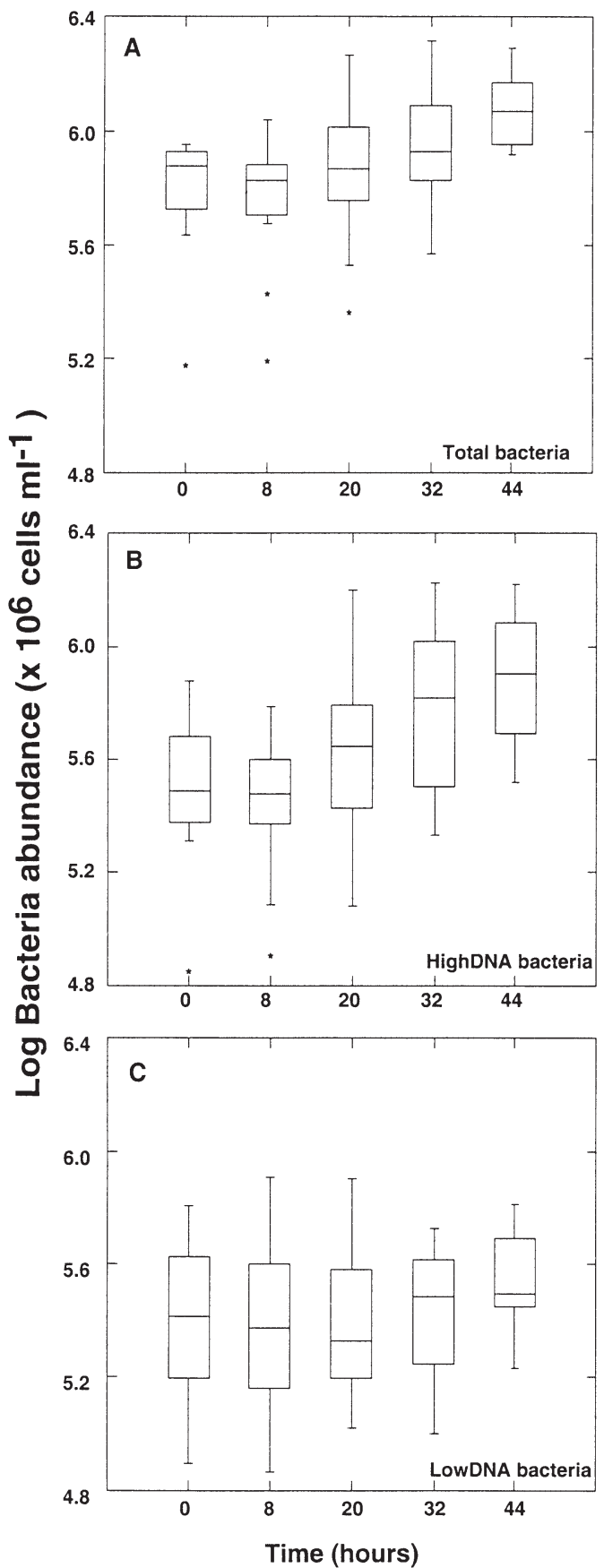

intervals changes in growth and losses of different bacterial subgroups or shown the link between total BP and consumption and the proportions of active bacteria. Some comments about the techniques used to measure grazing losses and to understand the meaning of what both bacterial subgroups represent are needed to be sure that the interpretation of our data is correct.

Several authors have already indicated that active bacteria are consumed at a higher rate than inactive bacteria by flagellate predators (Landry et al. 1991,
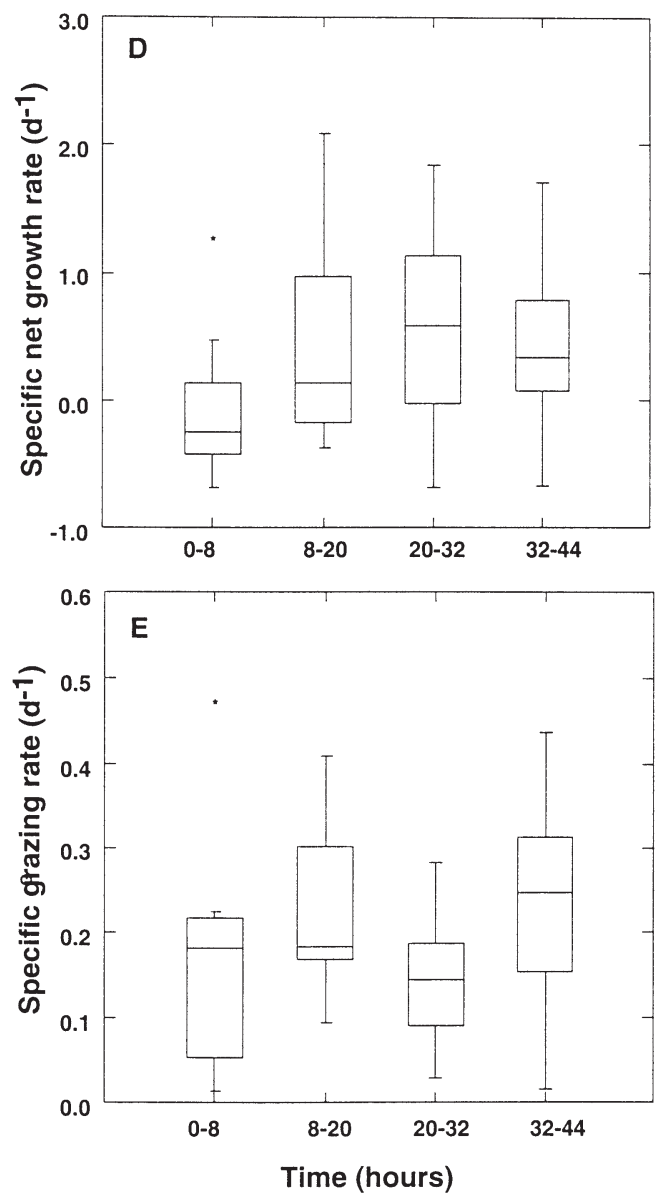

Fig. 6. Box plots of pooled data from incubation samples. (A) Total bacteria, (B) HighDNA bacterial and (C) LowDNA bacterial abundances, (D) specific net growth and (E) specific grazing rates. Horizontal lines within the boxes indicate the median of the distribution, and the box limits are the $25 \%$ quartiles of the data. The whiskers cover the entire data range, except for very extreme observations (*), some of which are off scale

Landry 1994, Epstein \& Rossel 1995, Christoffersen et al. 1997). Nevertheless, grazing on bacteria has been and still is being measured using either dead bacteria or plastic particles (e.g., FLB, minicells or latex beads; Sherr et al. 1987, Vaqué et al. 1992, 1994, Thouvenot et al. 1999). As with any 'heat-killed' fluorescent bacteria, DTAF-stained cells are perhaps not the best bacterial surrogates for measuring protozoan grazing rates. The main concern here is the assumption that they are preyed upon at the same rate as the natural active 


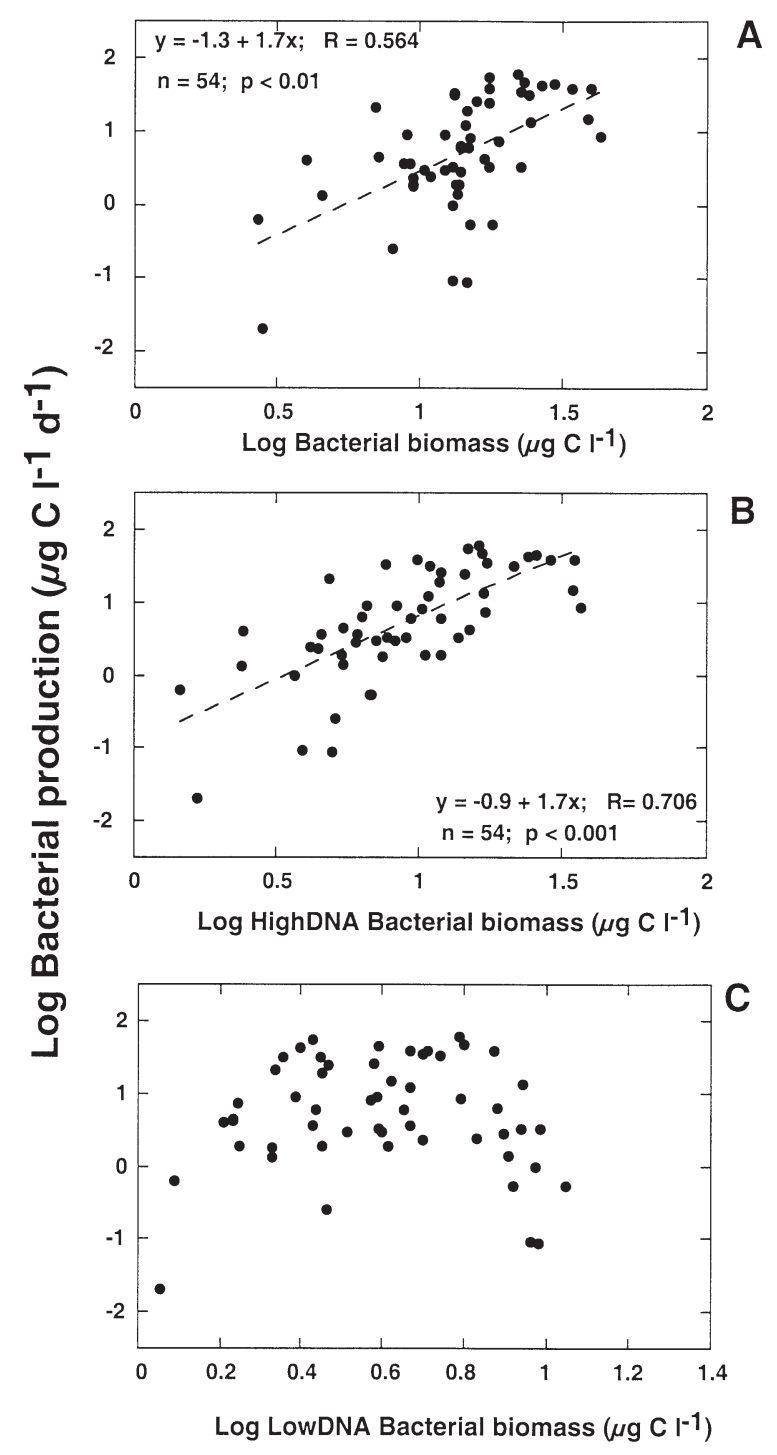

Fig. 7. Relation between bacterial production and (A) total bacterial biomass, (B) HighDNA bacterial biomass and

(C) LowDNA bacterial biomass for all experimental data

bacteria; in fact, we suspect that grazing rates may be underestimated. This is a problem broadly discussed in several review papers and we will not add any new insight (e.g., Landry 1994, Vaqué et al. 1994). Although the stained Pseudomonas diminuta are inactive bacteria, we think that the rates of ingestion were related mostly to their size $\left(0.065 \mu^{3}\right)$, which is always larger than that estimated for LowDNA bacteria. Thus, at time 0 , the average sizes of total, HighDNA and LowDNA bacteria were estimated to be $0.065,0.075$ and $0.053 \mu^{3}$, respectively. Consequently, considering that HNF preferably graze on the larger bacteria (González et al. 1990, Kuuppo-Leinikki \& Kuosa 1990), quite a large amount of $P$. diminuta was probably being ingested together with the pool of HighDNA bacteria. We do not know exactly whether this occurs as we claim; however, we have some evidence that at least stained $P$. diminuta were consumed. For instance, when we observed the samples by epifluorescence microscopy, some DTAF-stained $P$. diminuta were found inside the HNF vacuoles. We have also presented evidence that the disappearance of $P$. diminuta was due to grazing and not to other types of losses or artifacts (Fig. 2). Furthermore, we observed that grazing rates increased in samples where higher proportions of active cells were found.

Understanding the concept of 'active' and 'inactive' bacteria, and agreeing on whether the fraction here called HighDNA are really the bacteria with a high content of DNA are not enough to solve scientific questions. Should we consider active bacteria to be those that are growing or those that are alive and maintain intact their external structures? Do inactive bacteria include dead bacteria, ghosts, cell fragments and large viruses or just the cells with a state of very low cellular activity? While nomenclature discussions are interesting, it is better to have tools that are comprehensive, even though we might not be able to correlate them with those previously used. Gasol et al. (1999) compared different methodologies to show that the HighDNA fraction is the dynamic member of the bacterial community. Thus, counts of cells with nuclear material content (NucCC bacteria; Zweifel \& Hagström 1995) and 'live' bacteria (as labeled using a commercial live/dead test; Haugland 1996) showed a good agreement with HighDNA bacterial abundances as determined using SYTO-13 (Gasol et al 1999). SYTO-13 is assumed to stain both DNA and RNA with a similar quantum yield (Haugland1996). However, Guindulain et al. (1997) found it to stain mainly DNA in natural marine samples, a result that had also been observed for other stains, such as TO-PRO and TOTO (Li et al. 1995). Other authors have shown experimentally that the proportions of highly respiring bacteria (measured using CTC) are well correlated with the proportions of HighDNA bacteria (Sintes \& del Giorgio pers. comm.). Recently, Gasol et al. (unpubl. data) also found a very good correlation between the amount of HighDNA bacteria and the amount of bacteria hybridizing with a universal eubacterial oligonucleotide probe in a eutrophic reservoir. Also, several experiments presented by Gasol et al. (1999) and E. Sintes \& P. A. del Giorgio (pers. comm.) found indirect evidence showing that the HighDNA bacteria is the bacterial fraction that responds to the changes in bacterial predation and nutrient availability.

The LowDNA fraction registered small variations over time in the experiments reported here. We do not know yet what mechanisms may be involved in the 
changes of the LowDNA bacterial fraction. Some explanations can be put forward. Grazing on bacteria by HNF or viral activity may be responsible for the production of LowDNA bacteria, if that fraction is composed mainly of dead or damaged cells. However, this fraction that we call LowDNA bacteria may include both of these types and intact but inactive bacterial cells. Then, nutrient availability may be the ultimate factor responsible for the variability in LowDNA bacteria, which would have the potential for being transformed again into HighDNA bacteria, as has been shown to occur with other measures of bacterial cellular activity (e.g., Choi et al. 1996, 1999). Indeed, the relations found in this study between HighDNA bacteria, and BP and grazing losses are in agreement with these observations that HighDNA bacteria can be considered as the active bacterial fraction.

\section{Comparison between in situ values and microbial dynamics in the experimental bottles}

Results found in situ gave a static picture of total bacterial abundance or biomass, proportion of active bacteria and BP. The significant relations found between HighDNA bacteria, and BP and grazing losses show that the latter are enhanced for this active bacterial community and not for the total bacterial community (Fig. 3). The most illustrative case was observed at the Palamós open-sea station, where total bacteria registered the highest abundance, while the \%HighDNA bacteria, BP and grazing losses were the lowest (Table 1). Observing the low proportion of HighDNA bacteria, we expected also to find low predator abundance at this site. Paradoxically, it was at this station that HNF and ciliate abundance were at the highest levels (Table 1). This apparent disagreement may be explained by the fact that HNF can feed on alternative prey of sizes larger than bacteria (e.g., phototrophic bacteria, picoeukaryotes, etc). Much evidence indicates that phototrophic picoplankton (e.g., cyanobacteria) can be preyed upon by HNF (Campbell \& Carpenter 1986, Fahnenstiel et al. 1991, Caron et al. 1999, Kuipers \& Witte 2000) and ciliates (Modigh 2001). At the Palamós open-sea station we found the highest Synechococcus abundance $\left(6.5 \times 10^{4}\right.$ cells ml ${ }^{-1}$, from 6 to 200 times higher than at the other stations; Vaqué unpubl. data) and the lowest \% HighDNA bacteria, BP and growth rates (Table 1). In addition, microscopic observations showed many HNF and ciliates with Synechococcus cells inside their food vacuoles. Indeed, the low \%HighDNA bacteria, the high \%LowDNA bacteria, and the low grazing rates recorded indicate that predators were using some alternative food items other than heterotrophic bacteria. Furthermore, besides alternative prey, this situation may re- flect a point in predator-prey oscillations where HNF have proliferated due to previous consumption of HighDNA bacteria.

Detailed observations of what occurred inside the bottles allowed us to describe the dynamics of bacterial growth and grazing losses. Regarding bacterial growth, significant relations were found between HighDNA bacterial biomass and BP using the whole experimental data set that reinforce the correspondence encountered between the same variables for the in situ samples (Figs 3 \& 7). These results are consistent with those obtained by Gasol et al. (1999). During a dilution and growth experiment, these authors found that the \%HighDNA and the rates of ${ }^{3} \mathrm{H}$-leucine incorporation were well correlated, while the fraction corresponding to LowDNA was not related at all with BP, thus identifying the HighDNA bacterial fraction as the active fraction of the bacterial community. In the same vein, labeling bacteria with ${ }^{3} \mathrm{H}$-leucine and separating different fractions according to apparent cell size and green DNA staining with a cell sorter, Lebaron et al. (2001) found that bacteria with more DNA had 7 times more specific activity than bacteria with less DNA. Hence, our results add further evidence that the fraction with more DNA is responsible for most of the total leucine uptake of the community and most of the total bacterial community growth. The grazing losses were better correlated with the active fraction of the bacterial community than with the total bacterial community, considering both the whole experimental data set, and only the initial values. Interestingly, we found that the disappearance of the added tracers (e.g., grazing) was not constant with time. At the very beginning ( 0 to $8 \mathrm{~h}$ ) bacterial carbon losses and production were roughly balanced at almost all stations except at the Palamós open-sea station (Fig. 5). Afterwards (8 to $20 \mathrm{~h}$ ), bacteria started to grow and reached the maximum growth rates between 20 and $44 \mathrm{~h}$. This trend was also observed when we pooled the whole data set (Fig. 6). During exponential growth and in the plateau, an increase in total bacterial cell volume was registered in all experiments. It is well known that average cell volume increases in exponentially growing bacteria (e.g., Ammerman et al. 1984, Sherr et al. 1992). Higher mean volumes were recorded in the Barcelona transect and at the Palamós coastal and slope stations (mean $0.076 \mu^{3}$ ) than at the Palamós open-sea station (mean $0.058 \mu^{3}$ ). An increase in HighDNA bacterial numbers and cell volumes, which is very conspicuous after $20 \mathrm{~h}$, would produce an increase in activity and abundance of predators that can be translated into the grazing activity detected at the end of the experiments. In the case of the Palamós open-sea station it looks like this same pattern occurred but was delayed for roughly $12 \mathrm{~h}$. 
Therefore, considerable changes in HighDNA bacteria paralleled or preceded growth and grazing losses in the experiments reported and only small variations of LowDNA bacteria were detected (Fig. 4). It would also have been appropriate to count protists at each time interval or to extend the experiment for a few more hours, just to observe a decrease in HighDNA bacteria (percentage and biomass) and BP due to grazing losses. Similar results regarding the evolution of the different bacterial fractions (High and LowDNA) and showing changes in HNF abundances over longer periods of time ( 5 to $7 \mathrm{~d}$ ) have been described by Gasol et al. (1999) and by E. Sintes \& P. A. del Giorgio (pers. comm.). These authors found that the maximum abundance of HNF appeared when a dramatic decay of HighDNA bacteria was recorded.

The opportunity to follow the dynamics of the bacterial assemblages distinguishing active from inactive cells simultaneously with BP and grazing losses adds a further step in the understanding of the functioning of microbial food webs. Although we know that in experimental bottles, bacterial community structure and metabolic activity can deviate dramatically from those of in situ bacterial assemblages due to the so-called 'bottle effect' (Fuchs et al. 2000), this fate does not restrict the conclusions obtained on the dynamics of the different bacterial subgroups. We do not try here to extrapolate our results to nature; however, what we present hints at what may happen in natural environments when 1 or another subgroup of bacteria with a different DNA content dominates the total assemblage. The challenge for the future is to determine the number and type of phylotypes constituting the active component, as compared with that of the inactive fraction (Bernard et al. 2001), and to detect whether there is any shift up from one type to another and the causes that force this change.

Acknowledgements. This work was supported by the MAR 98-0932 project. We are very grateful to Sandra Bonache and Jordi Felipe for assistance in the laboratory and to Beatriz Díez, who helped in onboard sampling. We also thank Laura Arin for processing chl a concentration in water samples and Mikhail Emilianov for providing temperature data. We appreciate the helpful comments provided by Cesc Peters on a previous version of the manuscript and thank 3 anonymous reviewers for their thoughtful inputs. We also thank all cruise participants and the crew of the RV 'Garcia del Cid' for their help.

\section{LITERATURE CITED}

Ammerman JW, Fuhrman JA, Hagström ^̊, Azam F (1984) Bacterioplankton growth in seawater. I. Growth kinetics and cellular characteristics in seawater cultures. Mar Ecol Prog Ser 18:31-39

Bernard L, Courties C, Duperray C, Schäfer H, Muyzer G, Lebaron P (2001) A new approach to determine the genetic diversity of viable and active bacteria in aquatic ecosystems. Cytometry 43:314-321

Børsheim KY, Bratbak G (1987) Cell volume to cell carbon conversion factors for a bacterivorous Monas sp. enriched from seawater. Mar Ecol Prog Ser 36:171-175

Campbell L, Carpenter EJ (1986) Estimating the grazing pressure of heterotrophic nanoplankton on Synechococcus spp. using the sea water dilution and selective inhibitor techniques. Mar Ecol Prog Ser 33:121-129

Caron DA, Peele ER, Lim EI, Dennett MR (1999) Picoplankton and nanoplankton and their trophic coupling in surface waters of the Sargasso Sea south Bermuda. Limnol Oceanogr 44:259-272

Christoffersen K, Nybroe O, Jürgens K, Hansen M (1997) Measurement of bacterivory by heterotrophic nanoflagellates using inmunofluorescence labeling of ingested cells. Aquat Microb Ecol 13:127-134

Choi JW, Sherr EB, Sherr BF (1996) Relation between presence-absence of a visible nucleoid and metabolic activity in bacterioplankton cells. Limnol Oceanogr 41:1161-1168

Choi JW, Sherr EB, Sherr BF (1999) Dead or alive? A large fraction of ETS-inactive marine bacterioplankton cells, as assessed by reduction of CTC, can become ETS-active with incubation and substrate addition. Aquat Microb Ecol 18:105-115

del Giorgio PA, Gasol JM, Vaqué D, Mura P, Agustí S, Duarte CM (1996a) Protistan control of the proportion of metabolically active cells in coastal marine bacterioplankton. Limnol Oceanogr 41:1169-1179

del Giorgio PA, Bird DF, Prairie YT, Planas D (1996b) Flowcytometric determination of bacterial abundance in lake plankton with the green nucleic acid stain SYTO-13. Limnol Oceanogr 41:783-789

Epstein SS, Rossel J (1995) Methodology in in situ grazing experiments: evaluation of a new vital dye for preparation of fluorescently labeled bacteria. Mar Ecol Prog Ser 128: $143-150$

Fahnenstiel GL, Carrick HJ, Iturriaga R (1991) Physiological characteristics and food-web dynamics of Synechococcus in Lake Huron and Michigan. Limnol Oceanogr 36: 219-234

Fenchel T (1982) Ecology of heterotrophic microflagellates. II. Bioenergetics and growth. Mar Ecol Prog Ser. 8:225-231

Fuchs BM, Zubkov MV, Sahm K, Burkill PH, Amann R (2000) Changes in community composition during dilution cultures of marine bacterioplankton as assessed by flow cytometric and molecular biological techniques. Environ Microbiol 2:191-201

Gasol JM, del Giorgio PA (2000) Using flow cytometry for counting natural planktonic bacteria and understanding the structure of planktonic bacterial communities. Sci Mar 64:197-224

Gasol JM, Morán XAG (1999) Effects of filtration on bacterial activities and picoplankton community structure as assessed by flow cytometry. Aquat Microb Ecol 16:251-264

Gasol JM, del Giorgio PA, Massana R, Duarte CM (1995) Active versus inactive bacteria: size dependence in a coastal marine plankton community. Mar Ecol Prog Ser 128:91-97

Gasol JM, Zweifel UL, Peters F, Fuhrman JA, Hagström ^̊ (1999). Significance of size and nucleic acid content heterogeneity as measured by flow cytometry in natural planktonic bacteria. Appl Environ Microbiol 65:4475-4483

González JM, Sherr EB, Sherr BF (1990) Size-selective grazing on bacteria by natural assemblages of estuarine flagellates and ciliates. Appl Environ Microbiol 56:583-589

Guindulain T, Comas J, Vives-Rego J (1997) Use of nucleic 
acid dyes SYTO-13, TOTO-1 and YOYO-1 in the study of Escherichia coli and marine prokaryotic populations by flow cytometry. Appl Environ Microbiol 63:4608-4611

Haugland RP (1996) Handbook of fluorescent probes and research chemicals. Molecular Probes Inc, Eugene

Jürgens K, Güde H (1994) The potential importance of grazing resistant bacteria in planktonic systems. Mar Ecol Prog Ser 112:169-188

Kirchman DL (1993) Leucine incorporation as a measure of biomass production by heterotrophic bacteria. In: Kemp PF, Sherr, BF, Sherr EB, Cole JJ (eds). Handbook of methods in aquatic microbial ecology. Lewis Publishers, Boca Raton, p 509-512

Kuipers BR, Witte HJ (2000) Prochlorophytes as secondary prey for heterotrophic nanoflagellates in the deep chlorophyll maximum layer of the (sub)tropical North Atlantic. Mar Ecol Prog Ser 204:53-63

Kuuppo-Leinikki P, Kuosa H (1990) Estimation of flagellate grazing on bacteria by size fractionation in the northern Baltic Sea. Arch Hydrobiol Beih Ergebn Limnol 34: 283-290

Landry MR, Lehner-Fournier JM, Sundstrom JA, Fagerness VL, Selph KE (1991) Discrimination between living and heat-killed prey by marine zooflagellate, Paraphysomonas vestita (Stokes). J Exp Mar Biol Ecol 146:139-151

Landry MR (1994) Methods and controls of measuring the grazing impact of planktonic protist. Mar Microb Food Webs 8:37-57

Landry MR, Haas LW, Fagerness VL (1984) Dynamics of microbial plankton communities: experiments in Kaneohe Bay, Hawaii. Mar Ecol Prog Ser 16:127-133

Leaky RJG, Archer SD, Grey J (1996) Microbial dynamics in coastal waters of East Antarctica: bacterial production and nanoflagellate bacterivory. Mar Ecol Prog Ser 142:3-17

Lebaron P, Servais P, Agogué H, Courties C, Joux F (2001) Does the high nucleic acid content of individual bacterial cells allow us to discriminate between active cells and inactive cells in aquatic systems? Appl Environ Microbiol 67:1775-1782

Li WKW, Jellett JF, Dickie PM (1995) DNA distribution in planktonic bacteria stained with TO-TO or TO-PRO. Limnol Oceanogr 40:1485-1495

Massana R, Gasol JM, Bjørnsen PK, Blackburn N, Hagström Å, Hietanen S, Hygum BH, Kuparinen J, Pedrós-Alió C (1997) Measurement of bacterial size via image analysis of epifluorescence preparations: description of an inexpensive system and solutions to some of the most common problems. Sci Mar 61:397-407

Modigh M (1999) Seasonal variations of photosynthetic ciliates at the Mediterranean coastal site. Aquat Microb Ecol 23:163-175

Monger BC, Landry MR (1991) Prey-size dependency of grazing by free-living marine flagellates. Mar Ecol Prog Ser 74: 239-248

Monger BC, Landry MR (1992) Size selective grazing by heterotrophic nanoflagellates. An analysis using live-stained bacteria and dual beam flow cytometry. Arch Hydrobiol Beih 37:173-185

Norland S (1993) The relationship between biomass and volume of bacteria. In: Kemp PF, Sherr BF, Sherr EB, Cole JJ (eds). Handbook of methods in aquatic microbial ecology. Lewis Publishers, Boca Raton, p 303-307

Pedrós-Alió C, Calderón-Paz JI, Guixa-Boixereu N, Estrada M, Gasol JM (1999) Bacterioplankton and phytoplankton biomass and production during summer stratification in the northwestern Mediterranean Sea. Deep-Sea Res I 46: 985-1019
Peters F (1994) Prediction of planktonic protistan grazing rates. Limnol Oceanogr 39:195-206

Peters F, Marrasé C, Gasol JM, Sala MM, Arin L (1998) Effects of turbulence on bacterial growth mediated through food web interactions. Mar Ecol Prog Ser 172:293-303

Porter KG, Feig YS (1980) The use of DAPI for identifying and counting the aquatic microflora. Limnol Oceanogr 25: 943-948

Putt M, Stoecker DK (1989) An experimentally determined carbon:volume ratio for marine oligotrichous ciliates from estuarine and coastal waters. Limnol Oceanogr 34: $1097-1104$

Salat J, Marrasé C (1994). Exponential and linear estimations of grazing on bacteria: effects on changes in the proportion of marked cells. Mar Ecol Prog Ser 104:205-209

Servais P, Courties C, Lebaron P, Trousselier M (1999) Coupling bacterial activity measurements with cell sorting by flow cytometry. Microb Ecol 38:180-189

Sherr BY, Sherr EB, Berman T (1983) Grazing, growth and ammonium excretion rates of a heterotrophic microflagellate fed with four species of bacteria. Appl Environ Microbiol 45:1196-1201

Sherr BF, Sherr EB, Fallon D (1987) Use of monodispersed fluorescently labeled bacteria to estimate in situ protozoan bacterivory. Appl Environ Microbiol 53:958-965

Sherr BF, Sherr EB, McDaniel J (1992) Effect of protistan grazing on the frequency of dividing cells in bacterioplankton assemblages. Appl Environ Microbiol 58: 2381-2385

Sieracki ME, Johnson PW, Sieburth JM (1985) Detection, enumeration, and sizing of planktonic bacteria by image analyzed epifluorescence microscopy. Appl Environ Microbiol 49:799-810

Simon M, Azam F (1989) Protein content and protein synthesis rates of planktonic marine bacteria. Mar Ecol Prog Ser 51:201-213

Smith DC, Azam F (1992) A simple economical method for measuring bacterial protein synthesis rates in seawater using ${ }^{3} \mathrm{H}$-leucine. Mar Microb Food Webs 6:107-114

Thouvenot A, Richardot M, Debroas D, Devaux J (1999) Bacterivory of metazooplankton, ciliates and flagellates in a newly flooded reservoir. J Plankton Res 21:1659-1679

Ullrich S, Karrassch B, Hoppe H-G, Jeskulke K, Mehrens M (1996) Toxic effects on bacterial metabolism of the redox dye 5-cyano-2, 3 ditolyl tetrazolium chloride. Appl Environ Microbiol 62:4587-4593

Vaqué D, Pace Ml, Findlay SEG, Lints D (1992) Fate of bacterial production in a heterotrophic ecosystem: grazing by protist and metazoans in the Hudson estuary. Mar Ecol Prog Ser 89:155-163

Vaqué D, Gasol JM, Marrasé C (1994) Grazing rates on bacteria: the significance of methodology and ecological factors. Mar Ecol Prog Ser 109:263-274

Vazquez-Dominguez E, Peters F, Gasol JM, Vaqué D (1999) Measuring the grazing losses of picoplankton. Methodological improvements to the use of fluorescently labeled tracers combined to fow cytometry. Aquat Microb Ecol 20: $111-128$

Verity PG, Langdon C (1984) Relationships between lorica volume, carbon, nitrogen and ATP content of tintinnids in Narragansett Bay. J Plankton Res 6:859-868

Yentsch CS, Menzel DW (1963) A method for the determination of phytoplankton chlorophyll and phaeophytin by fluorescence. Deep-Sea Res 10:221-231

Zweifel UL, Hagström Å (1995) Total counts of marine bacteria include a large fraction of non-nucleotid-containing bacteria (ghosts). Appl Environ Microbiol 61:2180-2185 